\title{
Low vitamin D levels are associated with high viral loads in patients with chronic hepatitis B: a systematic review and meta- analysis
}

Ye-Chao Hu ${ }^{1,2}$, Wei-Wei Wang ${ }^{1}$, Wei-Yun Jiang ${ }^{1}$, Chun-Qing Li $^{1}$, Jian-Chun Guo ${ }^{1}$ and Yun-Hao Xun ${ }^{1 *}$

\begin{abstract}
Background: Previous studies have investigated the vitamin D status in patients with chronic hepatitis B virus (HBV) infection and its relationship with HBV replication, the results however were inconsistent. The present metaanalysis was carried out to compare the vitamin D levels between patients with chronic hepatitis B (CHB) and healthy controls, and to determine whether vitamin D levels were correlated with HBV viral loads significantly.

Methods: A systematic search was conducted via PubMed, Web of Science, EMBASE and the Cochrane Library to identify eligible studies until September 28, 2017. We calculated pooled mean difference (MD) and 95\% confidence intervals $(\mathrm{Cl})$ to quantitatively estimate the difference of vitamin $\mathrm{D}$ levels between CHB patients and controls. In addition, correlation between serum vitamin D levels and HBV viral loads was defined by summary correlation coefficient ( $r$ value) and the corresponding $95 \% \mathrm{Cl}$.

Results: A total of 7 studies involving 814 CHB patients and 696 healthy controls were included. A significantly decreased vitamin D levels was found in CHB patients compared with healthy controls: pooled MD (95\% Cl) was $2.03 \mathrm{ng} / \mathrm{mL}(-2.60,-1.46)$. Latitude-stratified subgroup analysis indicated this difference was more obvious in low latitude areas, with a bigger pooled $\mathrm{MD}(95 \% \mathrm{Cl})$ of $-2.72 \mathrm{ng} / \mathrm{mL}(-4.57,-0.87)$. In addition, we observed an inverse correlation between serum vitamin D levels and HBV viral loads: pooled $r(95 \% \mathrm{Cl})$ was $-0.41(-0.54,-0.27)$.

Conclusions: Our results showed that vitamin D levels were lower in CHB patients than that of healthy controls and inversely correlated with HBV viral loads, although future comprehensive studies are needed to clarify the underlying mechanisms.
\end{abstract}

Keywords: Hepatitis B virus, Hepatitis B, chronic, Vitamin D deficiency, 25-hydroxyvitamin D, Meta-analysis

\section{Background}

Hepatitis B virus (HBV) infection remains an important public health problem worldwide $[1,2]$. Approximately one third of world's population has been infected, and over 350 million patients are suffering from chronic HBV infection [1-3]. The clinical manifestations of chronic HBV infection include an inactive carrier state, chronic hepatitis, cirrhosis and even hepatocellular carcinoma (HCC) $[4,5]$. The

\footnotetext{
* Correspondence: xyhao1977@126.com

${ }^{1}$ Department of Liver Diseases, Hangzhou Sixth People's Hospital/Xixi

Hospital of Hangzhou, Zhejiang University of Traditional Chinese Medicine, 2 Hengbu Road, Hangzhou 310023, China

Full list of author information is available at the end of the article
}

outcome of infection depends on the interactions between host and viral factors, including gender, age, immune response, HBV genotype, HBV DNA levels, etc. $[1,2,6]$.

Vitamin $\mathrm{D}$ is a fat-soluble vitamin including two forms: vitamin $\mathrm{D}_{3}$ or cholecalciferol and vitamin $\mathrm{D}_{2}$ or ergocalciferol [7]. Natural sources of vitamin D in humans are mostly cholecalciferol (also called vitamin $\mathrm{D}_{3}$ ) which is synthesized in the skin from 7-dehydrocholesterol by sunlight exposure. Cholecalciferol is firstly converted by the 25-hydroxylase to 25-hydroxyvitamin D (25OHD) in the liver and further by $1 \alpha$-hydroxylase in the kidney to produce bioactive vitamin $\mathrm{D}$ metabolite, 1,25-dihydroxyvita$\min \mathrm{D}\left[1,25(\mathrm{OH})_{2} \mathrm{D}\right][7,8]$. The $1,25(\mathrm{OH})_{2} \mathrm{D}$ acts through

(c) The Author(s). 2019 Open Access This article is distributed under the terms of the Creative Commons Attribution 4.0 International License (http://creativecommons.org/licenses/by/4.0/), which permits unrestricted use, distribution, and 
vitamin $\mathrm{D}$ receptor (VDR) in a large number of tissues to carry out its classical functions, including the regulation of calcium, phosphorus, and bone mineral homeostasis. It also has several noncalcemic functions, such as immunomodulatory, anti-inflammatory and anti-fibrotic properties, in the body [7-9]. Serum vitamin D level is affected by gender, season, latitude and genetic variations related to vitamin D metabolism [10]. Although there is no consensus on optimal levels of vitamin D in serum, a 25OHD level $<20 \mathrm{ng} / \mathrm{mL}(<50 \mathrm{nmol} / \mathrm{L})$ is considered to indicate vitamin $\mathrm{D}$ deficiency by most experts $[7,10]$. Vitamin $\mathrm{D}$ deficiency results in abnormalities in calcium, phosphorus, and bone metabolism. Also, it has been suggested to be involved in the pathogenesis of autoimmune disorders, type 2 diabetes, cancers and the course of several infectious diseases recently $[8,9]$. With regard to liver diseases, clinical evidence has shown that patients with chronic liver diseases such as chronic hepatitis $\mathrm{C}(\mathrm{CHC})$ and nonalcoholic fatty liver disease (NAFLD) are at higher risk of vitamin D deficiency [11]. Furthermore, low serum levels of $25 \mathrm{OHD}$ was reported to be an independent factor of adverse outcomes in alcoholic liver diseases [12] and impaired virological response to interferon-based therapy in $\mathrm{CHC}$ patients $[13,14]$. A meta-analysis also demonstrated high prevalence of vitamin D deficiency in $\mathrm{CHC}$ patients, and a better virological response in individuals with higher serum vitamin $\mathrm{D}$ levels or receiving vitamin D supplementation [15].

Previous study demonstrated that vitamin D deficiency is prevalent in patients with chronic HBV infection and the serum 25OHD levels are inversely correlated with HBV viral loads [16]. Since then, several additional studies have assessed the vitamin D status in HBV patients and its correlation with HBV replication. However, the results of these studies were inconclusive. The aims of this meta-analysis are to evaluate the vitamin D status in $\mathrm{CHB}$ patients compared with healthy population, as well as the possible association between 25OHD and HBV DNA levels.

\section{Methods}

This meta-analysis was conducted in accordance with Preferred Reporting Items for Systematic Reviews and Meta-Analyses (PRISMA) guidelines (Additional file 1: Data S1) [17].

\section{Data sources and search strategy}

Two authors (Y.C Hu, W.W Wang) independently searched articles on databases including PubMed, Web of Science, EMBASE and the Cochrane Library. The keywords used in our searches are as follows: "chronic hepatitis B", "hepatitis B", "vitamin D", "25OHD", and " $1,25(\mathrm{OH})_{2} \mathrm{D}$ ". The last search was performed on September 28, 2017.

\section{Study selection}

After removing duplicate articles, two authors (Y.C Hu, W.Y Jiang) independently screened the titles and abstracts for potentially relevant studies, and reviewed the full texts when necessary. Included studies had to meet the following criteria: (1) Observational studies of all designs; (2) Data on serum vitamin D values in treatment naïve CHB patients (because both IFN- $\alpha$ and some nucleos(t)ide analogues may have an effect on vitamin $\mathrm{D}$ metabolism) [16] and healthy controls; (3) The outcome was presented as mean vitamin $\mathrm{D}$ values and their standard deviations in patients and controls, or correlation coefficients between serum vitamin D levels and HBV DNA levels; (4) Because HBV DNA levels in the original studies were log-transformed before analysis, Spearman's correlation coefficient, instead of Pearson's correlation coefficient, was applied in this study. As for exclusion criteria, reviews, case reports, conference paper, editorials and irrelevant articles were excluded. Any disagreement was resolved by discussion, together with clinical experts consultation.

\section{Data extraction and quality assessment}

The following information was extracted from eligible articles: name of the first author, year of publication, country, study design, method used for the vitamin D assay, season of sampling, latitude, sample size, participant characteristics (gender, age), virological parameters (HBV genotype, HBV DNA levels, HBeAg status), serum vitamin $D$ levels, prevalence of vitamin $D$ deficiency in $\mathrm{CHB}$ groups, and correlation coefficients between serum vitamin D and HBV viral loads.

The methodological quality of studies was assessed by two authors (Y.C Hu, W.Y Jiang) independently using the Newcastle-Ottawa Scale (NOS) [18]. In general, $>7$ scores are regarded as a high quality while 5-7 scores are regarded as a moderate quality [19]. Any disagreement between authors was resolved as described above.

\section{Data synthesis and statistical analysis}

Mean difference (MD) with 95\% confidence interval (CI) was used to determine the difference of serum vitamin $\mathrm{D}$ levels between patients and control groups. When referring to the association between vitamin D and HBV viral loads, all the correlation coefficients ( $r$ values) were firstly transformed to Fisher's $\mathrm{Z}$ values using Fisher's $\mathrm{r}$ to $\mathrm{Z}$ transformation (Formula 1). Standard errors of correlation coefficients were calculated with Formula 2 and Formula 3. Then summary Fisher's $Z$ value was calculated with the generic inverse variance method. The result was finally transformed back to the original correlation coefficient metric (Formula 4) [20, 21]. Formulas 1-4 are shown in (Additional file 2: Figure S1). 
Heterogeneity between studies was estimated using Cochran $Q$ test and $I^{2}$ statistics. $P<0.05$ or $I^{2}>50 \%$ indicated significant heterogeneity, and these data were analyzed with random-effects model to accommodate diversity. Otherwise, the fixed-effects model was applied [22, 23].

For any heterogeneity, sensitivity analyses were performed to indentify individual study's effect on pooled results and test the reliability of results. Funnel plots and Egger's test were used to assess the potential presence of publication bias. All statistical analyses were conducted using Stata version 12.0 software (Stata Corp LP, College Station, Texas) and R, version 3.3.1 for Windows (http://www.r-project.Org/).

\section{Results}

\section{Search results and study selection}

Our search identified 1083 articles, of which 309 were removed as duplicate publications and 698 were excluded after screening titles and abstracts. Therefore, a total of 76 articles were retained for full-text review, and 69 articles were excluded for other reasons (1 letter, 2 editorials, 3 did not report the method of correlation analysis, 30 conference papers and 33 did not report the outcome of interest). Finally, 7 eligible articles involving 814 patients with HBV infection cases and 696 controls were included in this meta-analysis [24-30]. The screening process was detailed in Fig. 1.

\section{Study characteristics and quality assessment}

The included studies were published between 2012 and 2017. All the studies were reported as full-text articles in English. 5 studies were conducted in Asia, 1 in Middle East and 1 in Europe.

All the studies were observational studies. One study [28] only involved pregnant women and one only involved men [30]. Two studies [27, 29] involved HBV patients with different clinical stages, including $\mathrm{CHB}$, cirrhosis and HCC. And one study [24] involved patients with viral hepatitis B or C. Only the appropriate data of $\mathrm{CHB}$ patients in each study was singled out for this meta-analysis.

All but one [24] of the studies reported the proportion of gender among $\mathrm{CHB}$ patients, yet no gender specific level of vitamin D was available. Four studies [24, 26, 28, 29]

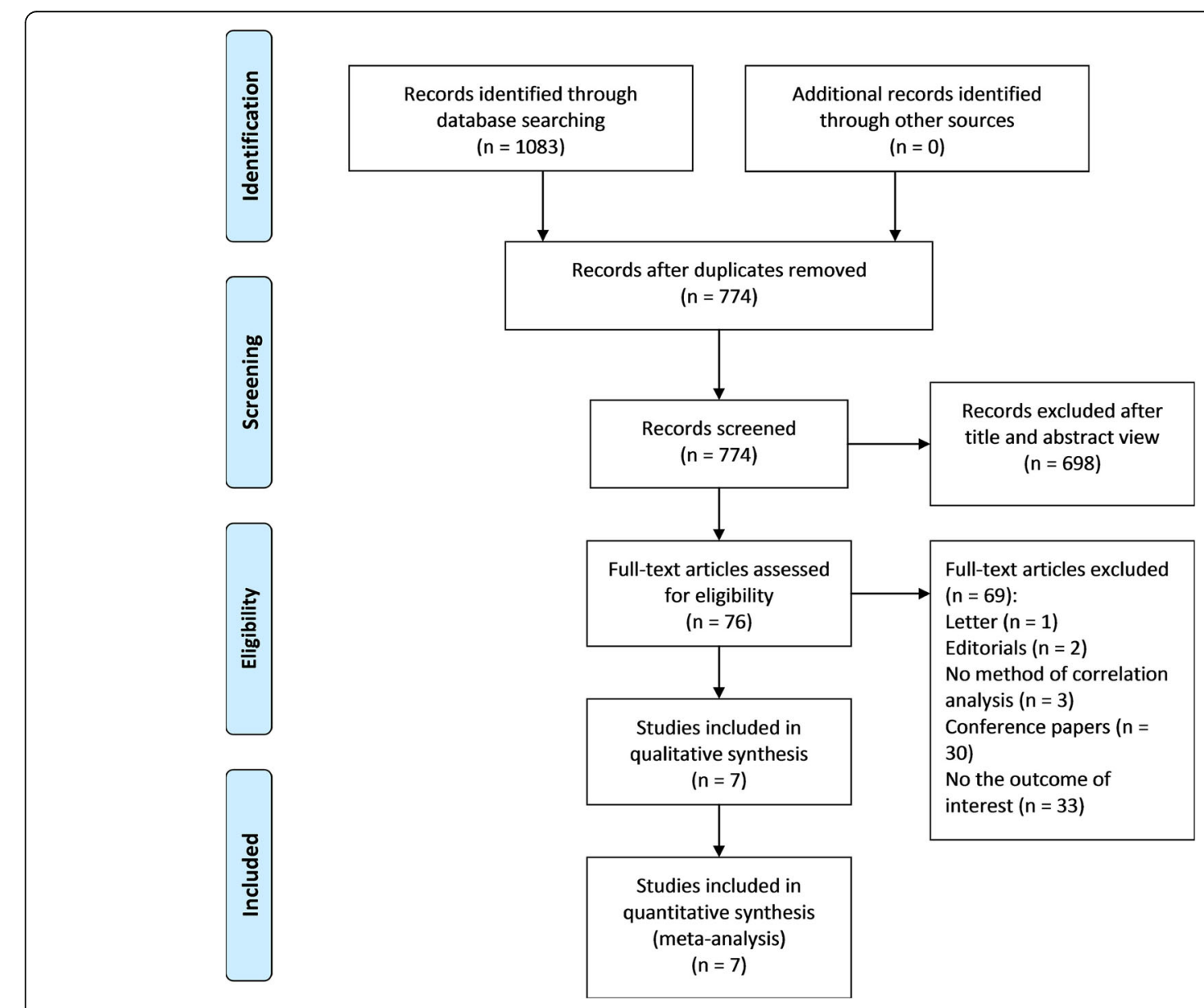

Fig. 1 PRISMA flow diagram of the study selection process 
mentioned the seasons of blood sampling but the seasons were different from each other, and no seasonally fluctuation was showed in Chen's study which extensively addressed the seasonality of serum vitamin D [26]. Only one study [26] reported HBV genotype. Two studies [26, 29] explored the differences of vitamin D level per HBeAg status and showed paradoxical results, with another study [28] indicating a comparable frequency of vitamin D deficiency. Thus no specific subgroup analyses about aforementioned items have been done.

Five studies $[25-28,30]$ reported the proportion of patients with vitamin D deficiency $(<20 \mathrm{ng} / \mathrm{mL})$ in $\mathrm{CHB}$ groups. And the pooled prevalence of vitamin D deficiency was 56\% (95\% CI: 23-89) (Fig. 2).

In addition, serum $25 \mathrm{OHD}$ was measured by different methods, including Enzyme-Linked Immunosorbent Assay, electrochemiluminescence, High Performance Liquid Chromatography Tandem Mass Spectrometry, and chemiluminescence. Even though, the interferences in this aspect are considered to be negligible, as reported by Zeng et al. [31].

Using the NOS assessment, 3 observational studies $[26,29,30]$ were found to be of high-quality and 4 observational studies $[24,25,27,28]$ were labeled as moderatequality studies. The characteristics and quality assessment of included studies are detailed in Table 1.

\section{Meta-analysis}

\section{Lower vitamin D levels in CHB patients}

Six studies [24, 26-30] involving $641 \mathrm{CHB}$ patients and 696 healthy controls were selected for this quantitative analysis. The units of $25 \mathrm{OHD}$ values were transformed from "nmol/L" to "ng/mL" $(2.5 \mathrm{nmol} / \mathrm{L}=1 \mathrm{ng} / \mathrm{mL})$ [9] to maintain consistency. The average serum 25OHD levels were significantly lower in $\mathrm{CHB}$ patients than that in controls, and pooled $\mathrm{MD}(95 \% \mathrm{CI})$ was $-2.03 \mathrm{ng} / \mathrm{mL}(-2.60,-1.46)$ (Cochran $Q$ test $P=0.384, I^{2}=5.1 \%$ ) (Fig. 3).

Sensitivity analysis, performed by deleting one single study each time from analysis, showed no individual study affected the result significantly, indicating that our result was robust (Fig. 4).

Funnel plot was relatively symmetrical, as displayed in Fig. 5. The result of Egger's test also suggested no evidence of potential publication bias $(P=0.497)$.

\section{Subgroup analysis}

A gradient change in 25OHD level according to latitude was observed [10]. We therefore conducted subgroup analysis based on latitude of the geographical locations where the studies were performed. The vitamin D levels were also lower in $\mathrm{CHB}$ patients compared with healthy controls, irrespective of latitude (Fig. 6). This difference was more obvious in low latitude areas [pooled MD $(95 \% \mathrm{CI})$ was $-2.72 \mathrm{ng} / \mathrm{mL}(-4.57,-0.87)]$.

\section{Inverse correlation between vitamin $D$ and HBV DNA levels}

We selected three studies [25-27] in which the relationship between vitamin D and HBV DNA levels was reported. When estimating a pooled correlation coefficient between serum 25OHD levels and HBV viral loads, a moderate heterogeneity between studies was observed, the random-effects model thereby was employed for the analysis. The result showed that the 25OHD levels was inversely correlated with HBV viral loads [summary Fisher's $\mathrm{Z}$ value $=-0.44$ (Cochran $Q$ test $\left.P=0.11, I^{2}=55 \%\right)$ (Fig. 7); after turning to initial $\mathrm{r}$, pooled $\mathrm{r}(95 \% \mathrm{CI})$ was $-0.41(-0.54,-0.27)]$.

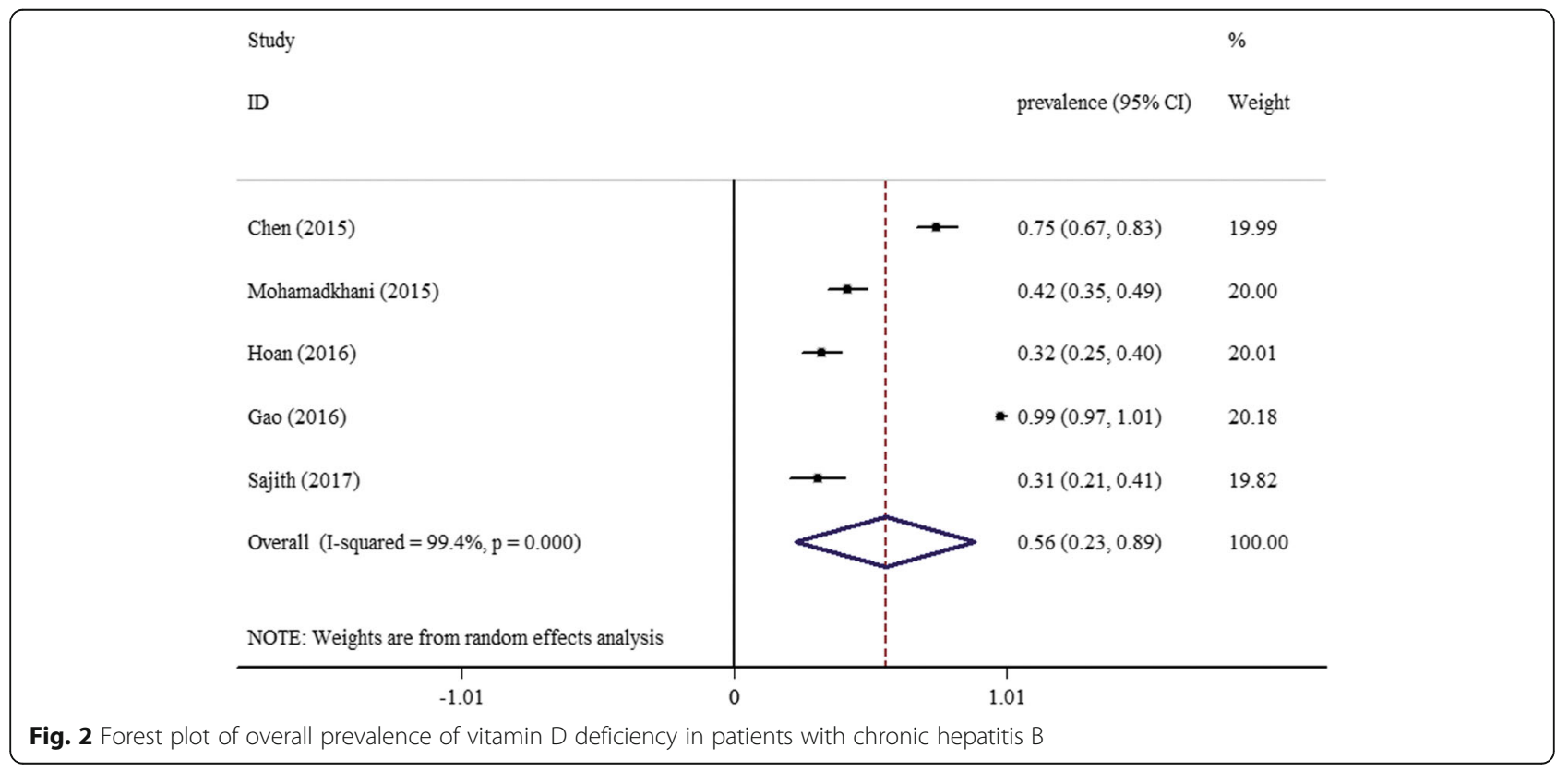




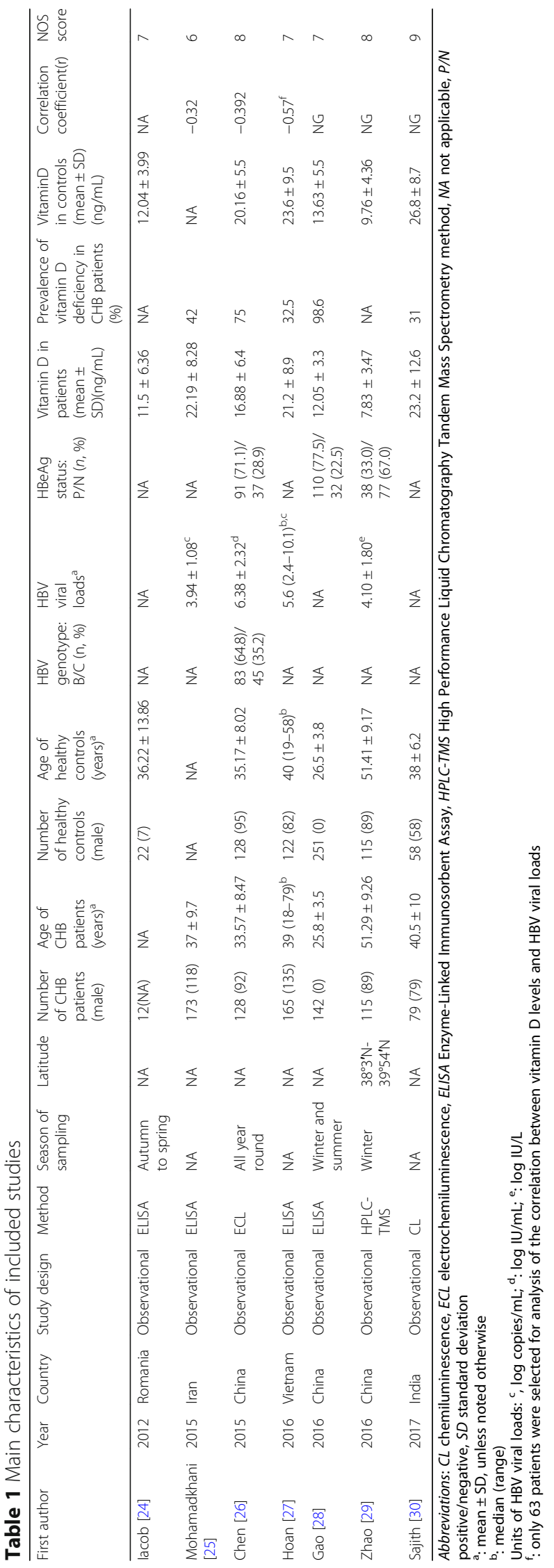




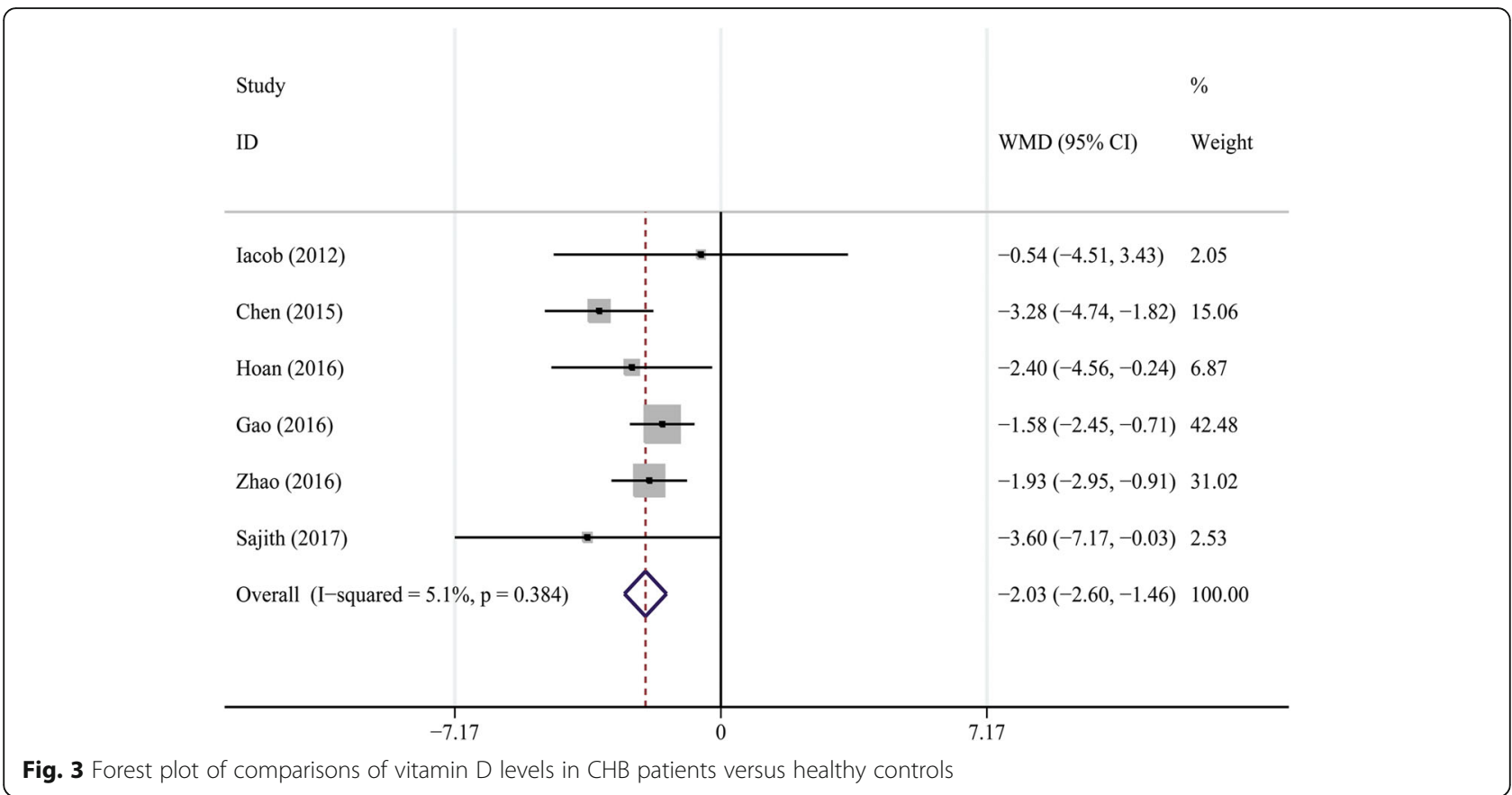

Sensitivity analysis indicated that the study reported by Hoan and colleagues [27] was responsible for the heterogeneity. When this study was deleted, this heterogeneity reduced remarkably, with little influence on the analytical outcome [summary Fisher's $\mathrm{Z}$ value $=-0.37$ (Fig. 8); after turning to initial $r$, pooled $r(95 \% \mathrm{CI})$ was $-0.35(-0.45,-0.25)]$.
Funnel plot appeared asymmetric, indicating the possible publication bias (Fig. 9). However, due to the limited number of studies, Egger's test cannot be conducted.

\section{Discussion}

This meta-analysis evaluated the differences of vitamin $\mathrm{D}$ levels in $\mathrm{CHB}$ patients compared with healthy

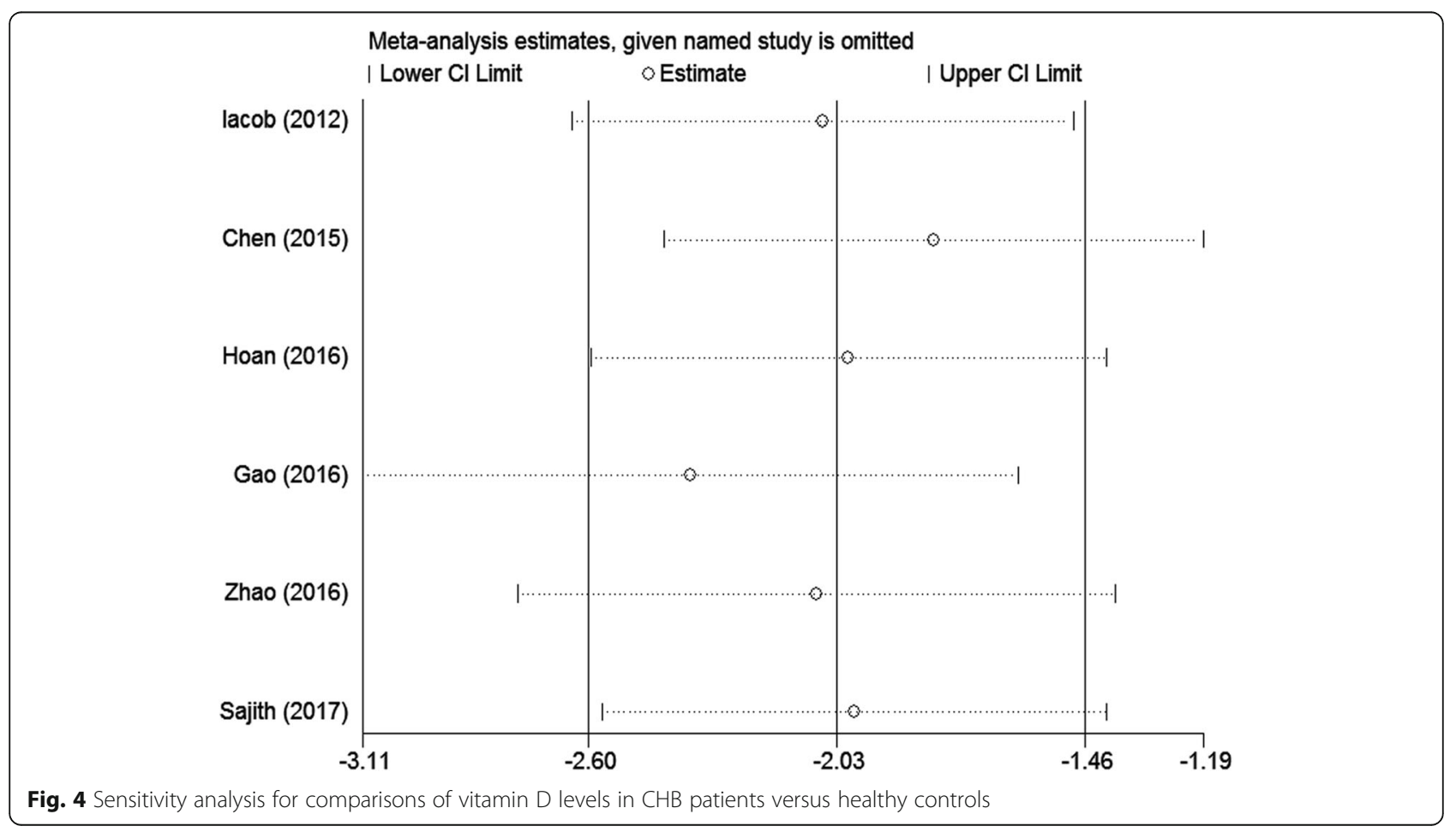




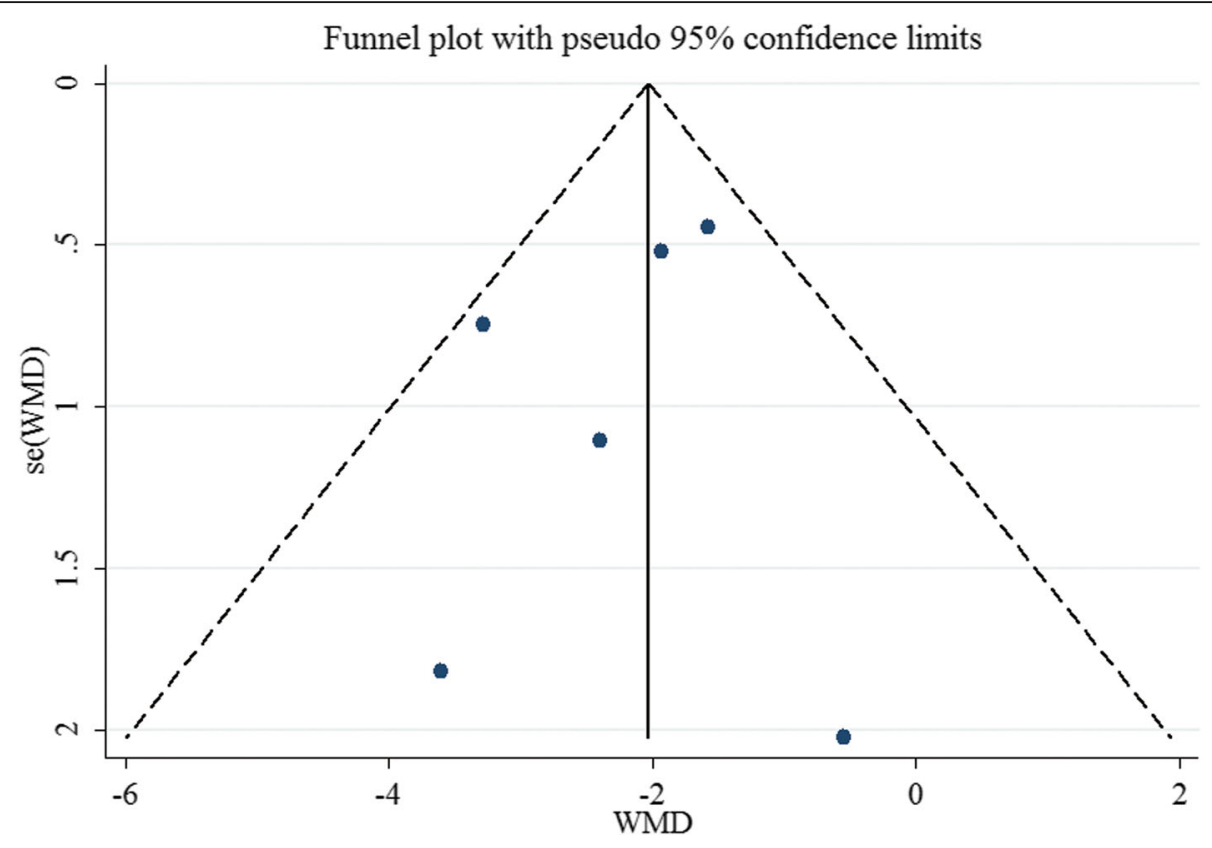

Fig. 5 Funnel plot for publication bias analysis for vitamin D levels in CHB patients versus healthy controls

population and its correlation with HBV DNA levels. The key findings from our study are: (1) a significantly lower vitamin D levels in CHB patients with a $2.03 \mathrm{ng} / \mathrm{mL}$ decrease of vitamin D levels, compared with healthy controls, (2) an inverse correlation between serum 25OHD levels and HBV viral loads.

Several explanations are possible for the low vitamin D levels in $\mathrm{CHB}$ patients. Firstly, liver is a pivotal organ in the activation of vitamin D. The 25-hydroxylation of vitamin $\mathrm{D}$ takes place in the liver to produce 25OHD. This process is mediated by the 25-hydroxylases, including the microsomal CYP2R1 and the mitochondrial CYP27A1 enzymes $[7,8]$. In addition, vitamin D-binding protein (DBP), the major carrier protein of $25 \mathrm{OHD}$ in the circulation, is exclusively synthesized by the liver [7]. Both of the enzymes and DBP are implicated with liver

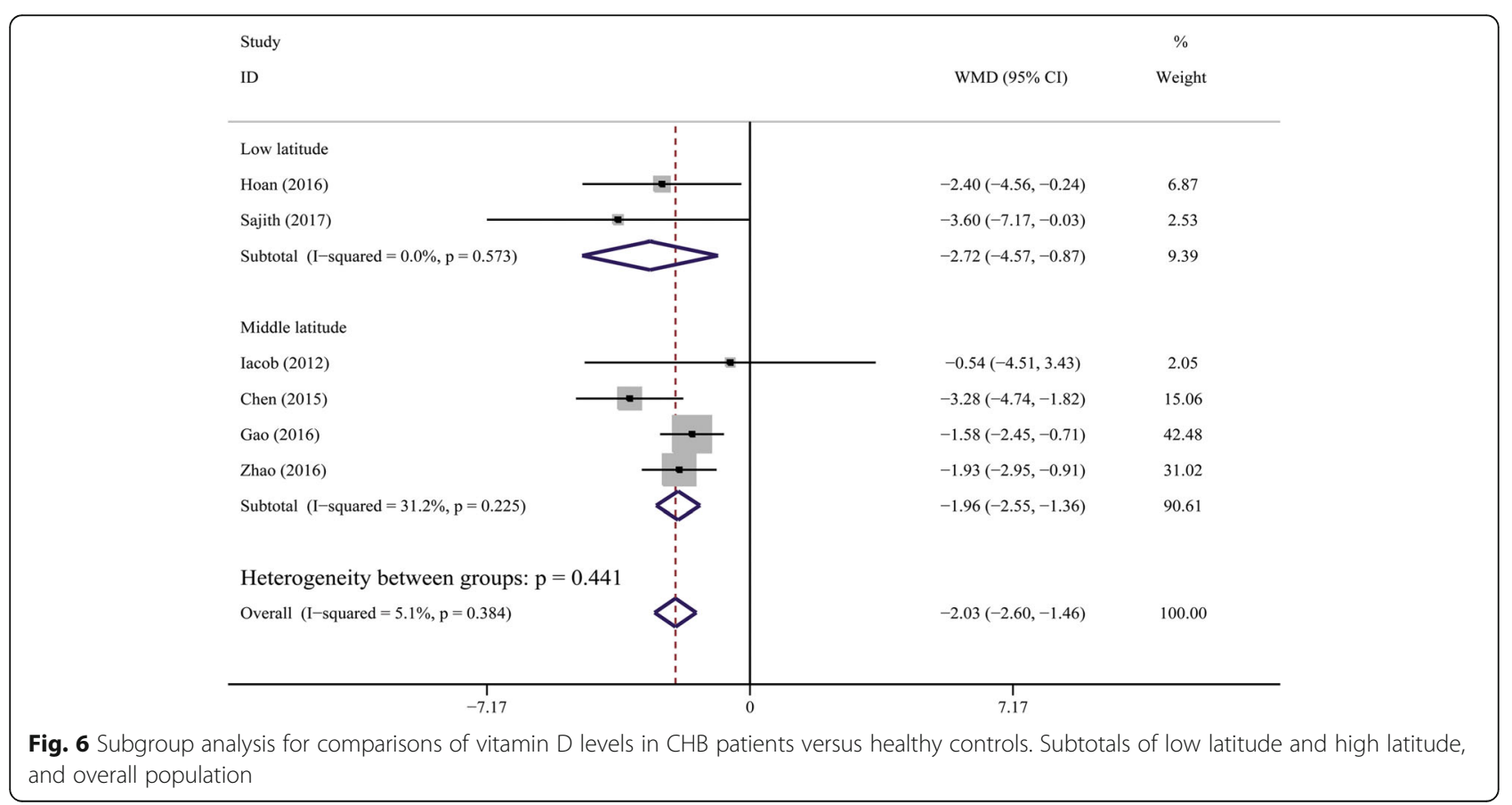




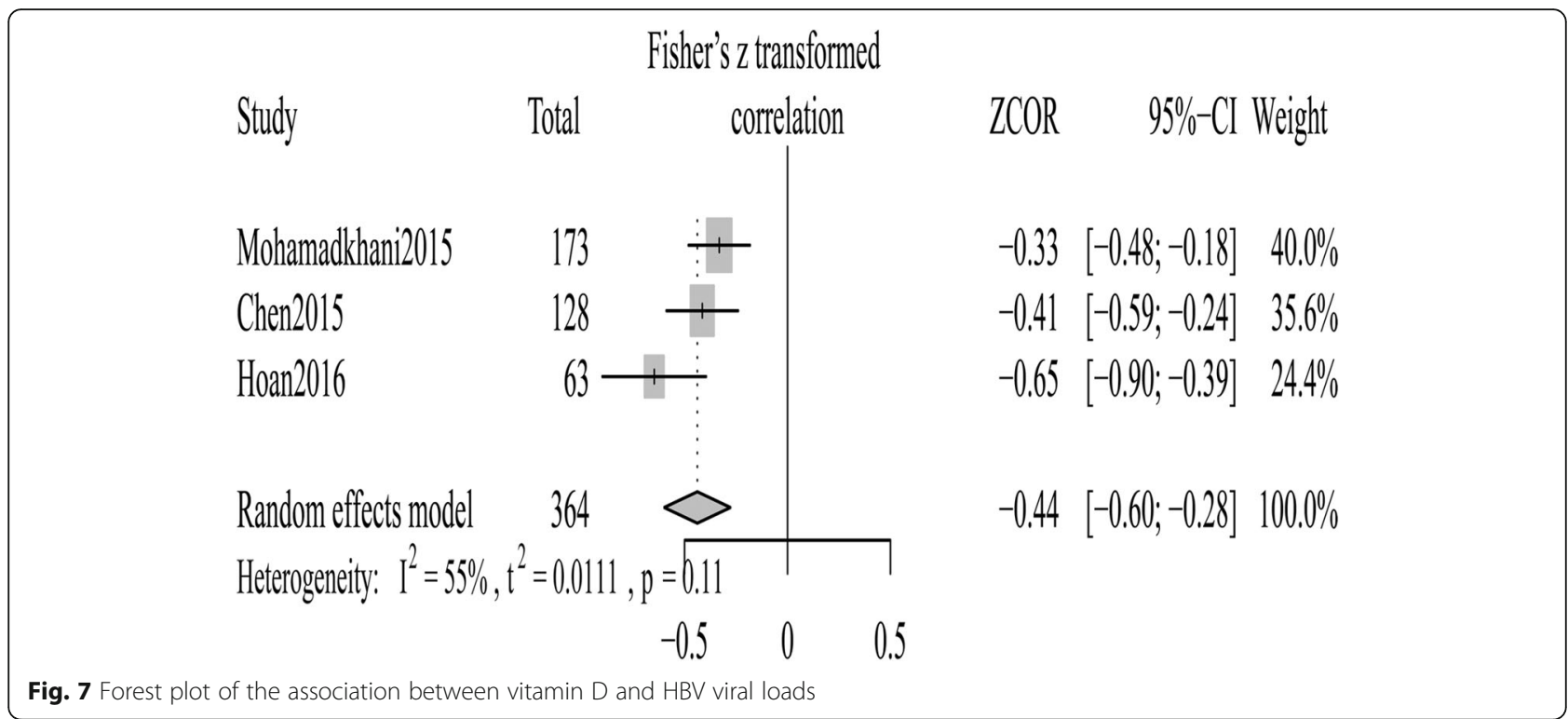

function. Thus the liver dysfunction of $\mathrm{CHB}$ patients could be a potential factor that contributed to the low vitamin D levels in these patients. Secondly, sunlight is an important determinant of vitamin D status via its initial generation in the skin [10]. Previous study [32] suggested that $\mathrm{CHB}$ patients had significantly lower physical activity levels than population norms, which may lead to a limited sunlight exposure and thereby a decreased vitamin D levels. Thirdly, a recent study [29] found that CYP24A1, an enzyme for degrading 25OHD and 1, $25(\mathrm{OH})_{2} \mathrm{D}$, was significantly upregulated in $\mathrm{CHB}$ patients when compared with healthy controls. Therefore, the imbalance of production and degradation of vitamin $\mathrm{D}$ could result in the vitamin D deficiency in CHB patients.
Subgroup analysis showed that the vitamin D levels were also lower in CHB patients compared with health controls, irrespective of latitude and this difference was more obvious in low latitude areas. In fact, several reviews found high prevalence of vitamin D deficiency worldwide, including countries of low latitude [33]. As for the Sajith's study which was performed in low latitude country (India) [30], the decrease of vitamin D levels reached up to $3.60 \mathrm{ng} / \mathrm{mL}$ (most significant among included articles) in CHB patients compared with health controls (Fig. 6). Earlier studies showed that the vitamin D status is particularly poor in India, despite being a tropical country [34, 35]. And the possible reasons include inadequate direct sunlight exposure (due to the

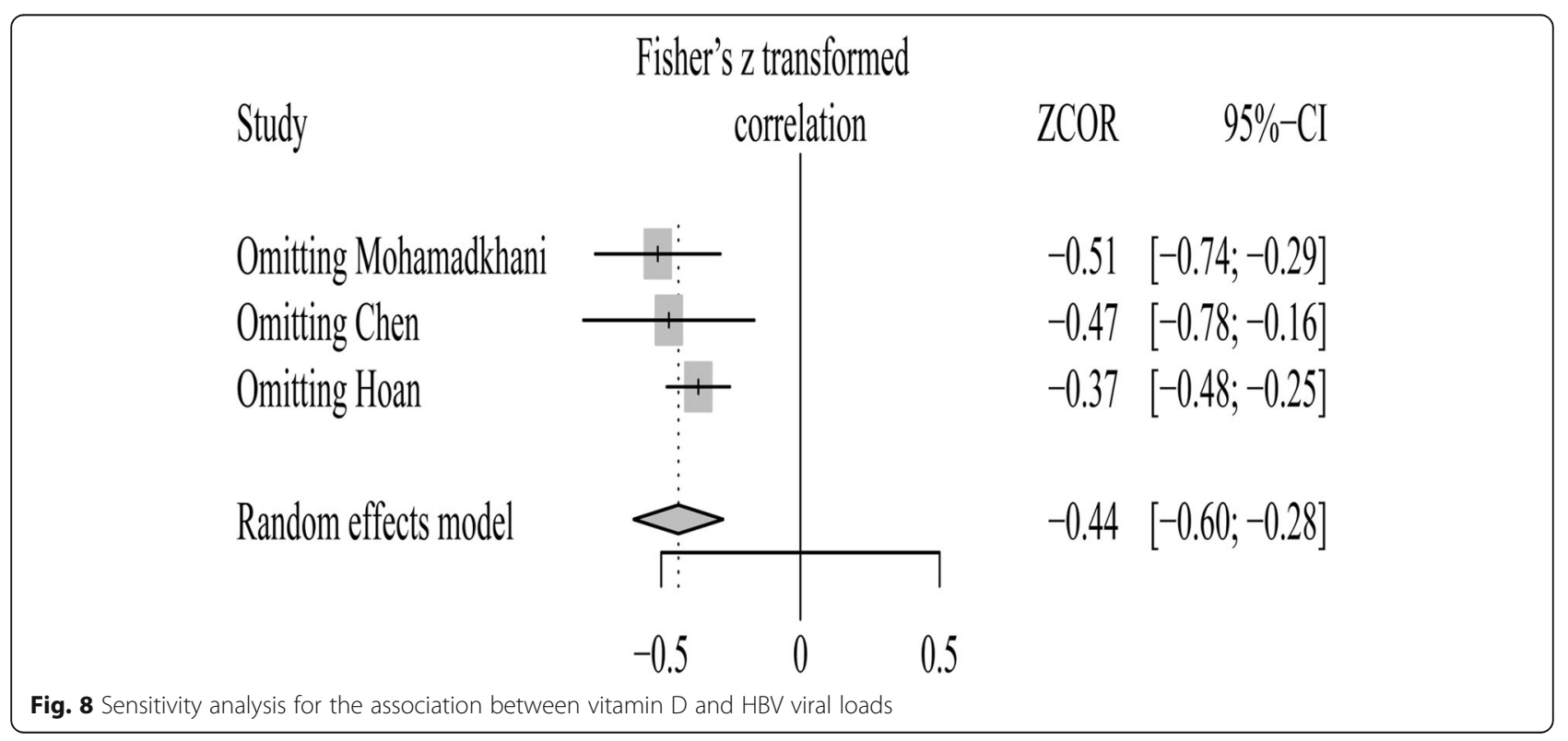




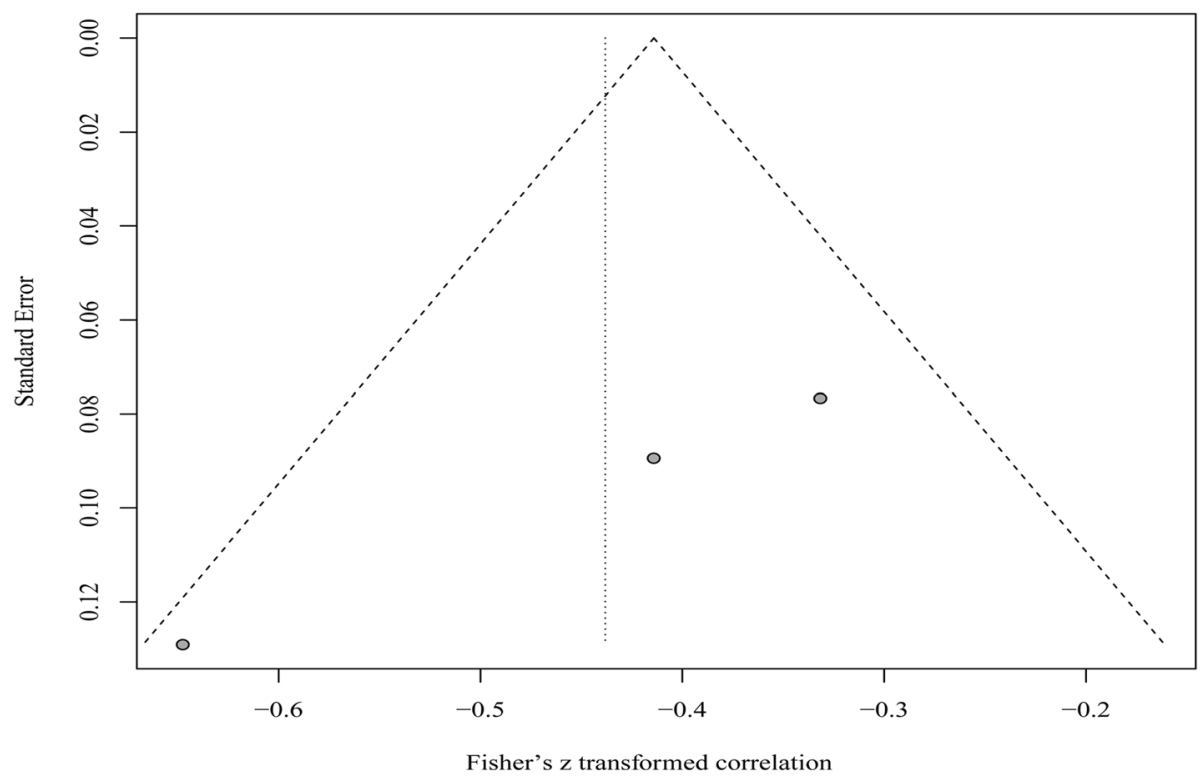

Fig. 9 Funnel plot for publication bias analysis for the association between vitamin D and HBV viral loads

traditional, conservative pattern of clothing, etc.), and food habits, all of them potentially hamper the photosynthesis of vitamin D in the body [35-38].

It has been well established that host immune response significantly influence the pathogenesis of HBV infection $[39,40]$. A weak immune response to HBV was found in chronic HBV infection [41]. Recent studies have shown that vitamin $\mathrm{D}$ has an important role in modulating both innate and adaptive immunity [7, $8,27]$. Various immune cells such as macrophages, B cells, $T$ cells and antigen-presenting cells express VDR $[7,26]$. And those $\mathrm{CD}^{+}$lymphocytes, the determining immune cells for HBV clearance, express the highest concentrations of VDR [42]. He et al [43] suggested that serum vitamin $\mathrm{D}$ levels have an obvious effect on the cellular immunity in $\mathrm{CHB}$ patients treated with interferon. The titer of HBV DNA decreased with the increase of serum vitamin $\mathrm{D}$ at baseline, and a higher level of serum 25OHD paralleled to a better virological response. Our meta-analysis demonstrates a negative relationship between vitamin $\mathrm{D}$ levels and HBV viral loads, though the number of relevant studies was only three. All these evidences indicate an important role of vitamin $\mathrm{D}$ in the immune response to HBV and even HBV replication itself. However, only three articles were enrolled and heterogeneity was found in our analysis. Therefore, the results should be interpreted with caution and more studies are needed to reach a robust conclusion in future. Also, it is still premature to recommend vitamin $\mathrm{D}$ supplementation for patients with $\mathrm{CHB}$ aiming to increase virological response.
In addition, vitamin $\mathrm{D}$ deficiency seems to be associated with disease progression in patients with chronic HBV infection. Wong et al [44] observed that serum 25OHD level was inversely correlated with Model for End-Stage Liver Disease score in $\mathrm{CHB}$ patients. And lower 25OHD level was an independent factor of long-term adverse outcomes. However, the exact cause of this relationship is far from clear. And meta-analysis in this regard is temporarily unavailable due to the limited information of relevant studies.

There were still several limitations in our metaanalysis. The major limitation is that the number of included articles was relatively small, which inevitably influence the stability of summarized results. Second, the CHB patients in our analysis was somehow underrepresented as one study only involved women, one only involved men and most included studies were from Asia. Third, the studies included in this work lacked information on either one or more characteristics (such as sampling season, gender, HBV genotype, HBeAg status), we could not perform stratified analysis by these items, the correspondingly influences on 25OHD level failed regretfully to be assessed and await more studies in future. Finally, the extraskeletal effects of vitamin D deficiency has been severely challenged, even raise the question about the real normal level of serum vitamin $\mathrm{D}$ in healthy population $[45,46]$. Hence, it remains to be determined whether vitamin $\mathrm{D}$ has an impact on the HBV replication and the outcome of HBV infection. 


\section{Conclusions}

The current meta-analysis demonstrated a significant lower vitamin D levels in CHB patients compared with healthy people and an inverse correlation between serum vitamin D levels and HBV viral loads. Considering the limitations of the present study, further well-designed, comprehensive researches are needed to address the remaining issues.

\section{Additional files}

Additional file 1: Data S1. PRISMA 2009 checklist. (DOC 74 kb)

Additional file 2: Figure S1. Conversion formulas. (TIF 34 kb)

\section{Abbreviations}

1,25(OH) $)_{2}$ D: 1,25-dihydroxyvitamin D; 25OHD: 25-hydroxyvitamin D; CHB: Chronic hepatitis B; CHC: Chronic hepatitis C; Cl: Confidence intervals; DBP: Vitamin D-binding protein; HBV: Hepatitis B virus; HCC: Hepatocellular carcinoma; MD: Mean difference; NAFLD: Non-alcoholic fatty liver disease; VDR: Vitamin D receptor

\section{Acknowledgments}

Not applicable.

\section{Authors' contributions}

YCH and YHX designed the study. YCH and WWW performed the research. YCH and WYJ reviewed articles, carried out data collection and quality assessment. CQL gave statistical support. YCH wrote the manuscript. JCG and YHX proofread and revised the manuscript. All authors read and approved the final manuscript.

\section{Funding}

This study was funded by the Science and Technology Development Plan Projects of Hangzhou, China (20140733Q40)

\section{Availability of data and materials}

All data and materials were presented within the manuscript and additional supporting files.

\section{Ethics approval and consent to participate}

Not applicable.

\section{Consent for publication}

Not applicable.

\section{Competing interests}

The authors declare that they have no competing interests.

\section{Author details}

${ }^{1}$ Department of Liver Diseases, Hangzhou Sixth People's Hospital/Xixi Hospital of Hangzhou, Zhejiang University of Traditional Chinese Medicine, 2 Hengbu Road, Hangzhou 310023, China. ${ }^{2}$ The First People's Hospital of Xiaoshan District, 199 Shixin South Road, Hangzhou 311200, China.

Received: 27 June 2018 Accepted: 30 May 2019

Published online: 11 June 2019

\section{References}

1. Trépo C, Chan HL, Lok A. Hepatitis B virus infection. Lancet. 2014;384(9959): 2053-63.

2. European Association for the Study of the Liver. Electronic address eee, European Association for the Study of the L: EASL 2017 clinical practice guidelines on the management of hepatitis B virus infection. J Hepatol. 2017;67(2):370-98.

3. Nannini P, Sokal EM. Hepatitis B: changing epidemiology and interventions. Arch Dis Child. 2017;102(7):676-80.
4. Tseng TC, Kao JH. Clinical utility of quantitative HBsAg in natural history and nucleos(t)ide analogue treatment of chronic hepatitis B: new trick of old dog. J Gastroenterol. 2013;48(1):13-21.

5. Moudi B, Heidari Z, Mahmoudzadeh-Sagheb H. Impact of host gene polymorphisms on susceptibility to chronic hepatitis B virus infection. Infect Genet Evol. 2016:44:94-105.

6. Mittal S, El-Serag HB. Epidemiology of hepatocellular carcinoma: consider the population. J Clin Gastroenterol. 2013;47(Suppl):S2-6.

7. Kitson MT, Roberts SK. D-livering the message: the importance of vitamin D status in chronic liver disease. J Hepatol. 2012;57(4):897-909.

8. Christakos S, Dhawan P, Verstuyf A, Verlinden L, Carmeliet G. Vitamin D: metabolism, molecular mechanism of action, and pleiotropic effects. Physiol Rev. 2016;96(1):365-408.

9. Rosen CJ. Clinical practice. Vitamin D insufficiency. N Engl J Med. 2011; 364(3):248-54

10. Yu R, Tan D, Ning Q, Niu J, Bai X, Chen S, Cheng J, Yu Y, Wang H, Xu M, et al. Association of baseline vitamin $\mathrm{D}$ level with genetic determinants and virologic response in patients with chronic hepatitis B. Hepatol Res. 2018; 48(3):E213-21.

11. Chen E-Q, Shi Y, Tang H. New insight of vitamin D in chronic liver diseases. Hepatobiliary Pancreat Dis Int. 2014;13(6):580-5.

12. Trepo E, Ouziel R, Pradat P, Momozawa Y, Quertinmont E, Gervy C, Gustot T, Degre D, Vercruysse $V$, Deltenre $P$, et al. Marked 25-hydroxyvitamin D deficiency is associated with poor prognosis in patients with alcoholic liver disease. J Hepatol. 2013:59(2):344-50.

13. Petta S, Camma C, Scazzone C, Tripodo C, Di Marco V, Bono A, Cabibi D, Licata G, Porcasi R, Marchesini G, et al. Low vitamin D serum level is related to severe fibrosis and low responsiveness to interferon-based therapy in genotype 1 chronic hepatitis C. Hepatology. 2010;51(4):1158-67.

14. Mandorfer M, Reiberger T, Payer BA, Ferlitsch A, Breitenecker F, Aichelburg MC, Obermayer-Pietsch B, Rieger A, Trauner M, Peck-Radosavljevic M. Low vitamin $D$ levels are associated with impaired virologic response to PEGIFN + RBV therapy in HIV-hepatitis C virus coinfected patients. Aids. 2013:27(2):227-32

15. Villar LM, Del Campo JA, Ranchal I, Lampe E, Romero-Gomez M. Association between vitamin D and hepatitis C virus infection: a meta-analysis. World J Gastroenterol. 2013;19(35):5917-24.

16. Farnik H, Bojunga J, Berger A, Allwinn R, Waidmann O, Kronenberger B, Keppler OT, Zeuzem S, Sarrazin C, Lange CM. Low vitamin D serum concentration is associated with high levels of hepatitis B virus replication in chronically infected patients. Hepatology. 2013;58(4):1270-6.

17. Liberati A, Altman DG, Tetzlaff J, Mulrow C, Gotzsche PC, loannidis JP, Clarke M, Devereaux PJ, Kleijnen J, Moher D. The PRISMA statement for reporting systematic reviews and meta-analyses of studies that evaluate healthcare interventions: explanation and elaboration. Bmj. 2009;339:b2700.

18. Wells GA SB, O'Connell D, Peterson J, Welch V, Losos M TP: The NewcastleOttawa scale (NOS) for assessing the quality of nonrandomised studies in meta-analyses 2000. http://www.ohri.ca/programs/clinical_epidemiology/ oxford.asp (Accessed 21 June 2016).

19. Khan MA, Akbar A, Baron TH, Khan S, Kocak M, Alastal Y, Hammad T, Lee WM, Sofi A, Artifon EL, et al. Endoscopic ultrasound-guided biliary drainage: a systematic review and meta-analysis. Dig Dis Sci. 2016;61(3):684-703.

20. Chalkidou A, Landau DB, Odell EW, Cornelius VR, O'Doherty MJ, Marsden PK. Correlation between Ki-67 immunohistochemistry and 18F-fluorothymidine uptake in patients with cancer: a systematic review and meta-analysis. Eur J Cancer. 2012;48(18):3499-513.

21. Brouwer WP, Chan HL, Brunetto MR, Martinot-Peignoux $M$, Arends $P$, Cornberg M, Cherubini B, Thompson AJ, Liaw YF, Marcellin P, et al. Repeated measurements of hepatitis B surface antigen identify carriers of inactive HBV during long-term follow-up. Clin Gastroenterol Hepatol. 2016; 14(10):1481-9 e5.

22. Han C, Lin R, Liu J, Hou X, Qian W, Ding Z. Endoscopic ultrasonographyguided biopsy for differentiation of benign and malignant pelvic lesions: a systematic review and meta-analysis. Dig Dis Sci. 2015;60(12):3771-81.

23. Hou F, Qi X, Guo X. Effectiveness and safety of Pleurodesis for hepatic hydrothorax: a systematic review and meta-analysis. Dig Dis Sci. 2016;61(11): 3321-34.

24. lacob SA, Panaitescu E, lacob DG, Cojocaru M. The human cathelicidin LL37 peptide has high plasma levels in B and C hepatitis related to viral activity but not to 25-hydroxyvitamin D plasma level. Rom J Intern Med. 2012;50(3):217-23. 
25. Mohamadkhani A, Bastani F, Khorrami S, Ghanbari R, Eghtesad S, Sharafkhah M, Montazeri G, Poustchi H. Negative Association of Plasma Levels of vitamin D and miR-378 with viral load in patients with chronic hepatitis B infection. Hepat Mon. 2015;15(6):e28315.

26. Chen EQ, Bai L, Zhou TY, Fe M, Zhang DM, Tang H. Sustained suppression of viral replication in improving vitamin D serum concentrations in patients with chronic hepatitis B. Sci Rep. 2015;5:15441.

27. Hoan NX, Khuyen N, Binh MT, Giang DP, Van Tong H, Hoan PQ, Trung NT, Anh DT, Toan NL, Meyer CG, et al. Association of vitamin D deficiency with hepatitis B virus - related liver diseases. BMC Infect Dis. 2016;16(1):507.

28. Gao XR, Wang CM, Wang WJ, Han GR, Zhang JQ. Serum 25-hydroxyvitamin D status in pregnant women with chronic hepatitis B virus infection. J Infect Dev Ctries. 2016;10(8):851-6.

29. Zhao XY, Li J, Wang JH, Habib S, Wei W, Sun SJ, Strobel HW, Jia JD. Vitamin D serum level is associated with child-Pugh score and metabolic enzyme imbalances, but not viral load in chronic hepatitis B patients. Medicine. 2016;95(27):e3926.

30. Sajith KG, Kapoor N, Shetty S, Goel A, Zachariah U, Eapen CE, Paul TV. Bone Health and Impact of Tenofovir Treatment in Men with Hepatitis-B Related Chronic Liver Disease. J Clin Exp Hepatol. 2017;8(1):23-7.

31. Zeng J, Wu G, Yang W, Gu X, Liang W, Yao Y, Song Y. A serum vitamin D level $<25 \mathrm{nmol} / /$ pose high tuberculosis risk: a meta-analysis. PLoS One. 2015;10(5):e0126014

32. Price JK, Srivastava R, Bai C, Diao G, Gerber LH, Younossi ZM. Comparison of activity level among patients with chronic liver disease. Disabil Rehabil. 2013;35(11):907-12.

33. Palacios C, Gonzalez L. Is vitamin D deficiency a major global public health problem? J Steroid Biochem Mol Biol. 2014;144 Pt A:138-45.

34. Lips P. Worldwide status of vitamin D nutrition. J Steroid Biochem Mol Biol. 2010;121(1-2):297-300

35. Sudhanshu S, Upadhyay P, Sahu M, Rawat V, Bhatia V. Sun exposure, UV irradiance and serum 25-hydroxycholecalciferol in pregnant women in rural North India. Public Health Nutr. 2017;20(10):1755-9.

36. Akhtar S. Vitamin D status in south Asian populations - risks and opportunities. Crit Rev Food Sci Nutr. 2016;56(11):1925-40.

37. Harinarayan CV, Holick MF, Prasad UV, Vani PS, Himabindu G. Vitamin D status and sun exposure in India. Dermatoendocrinol. 2013;5(1):130-41.

38. GR, Gupta A. Vitamin D deficiency in India: prevalence, causalities and interventions. Nutrients. 2014;6(2):729-75.

39. Isogawa M, Tanaka Y. Immunobiology of hepatitis B virus infection. Hepatol Res. 2015;45(2):179-89.

40. Zhang Z, Zhang JY, Wang LF, Wang FS. Immunopathogenesis and prognostic immune markers of chronic hepatitis B virus infection. J Gastroenterol Hepatol. 2012;27(2):223-30.

41. Stoop JN, van der Molen RG, Baan CC, van der Laan LJ, Kuipers EJ, Kusters $J G$, Janssen $\mathrm{HL}$. Regulatory $T$ cells contribute to the impaired immune response in patients with chronic hepatitis B virus infection. Hepatology. 2005:41(4):771-8.

42. Deluca HF, Cantorna MT. Vitamin D: its role and uses in immunology. FASEB J. 2001;15(14):2579-85.

43. He LJ, Zhang HP, Li HJ, Wang J, Chang DD. Effect of serum vitamin D levels on cellular immunity and antiviral effects in chronic hepatitis B patients. Clin Lab. 2016;62(10):1933-9.

44. Wong GL, Chan HL, Chan HY, Tse CH, Chim AM, Lo AO, Wong WW. Adverse effects of vitamin $D$ deficiency on outcomes of patients with chronic hepatitis B. Clin Gastroenterol Hepatol. 2015;13(4):783-90 e1.

45. Manson JE, Cook NR, Lee IM, Christen W, Bassuk SS, Mora S, Gibson H, Gordon D, Copeland T, D'Agostino D, et al. Vitamin D supplements and prevention of Cancer and cardiovascular disease. N Engl J Med. 2019; 380(1):33-44.

46. Pilz S, Trummer C, Pandis M, Schwetz V, Aberer F, Grubler M, Verheyen N, Tomaschitz A, Marz W. Vitamin D: current guidelines and future outlook. Anticancer Res. 2018;38(2):1145-51.

\section{Publisher's Note}

Springer Nature remains neutral with regard to jurisdictional claims in published maps and institutional affiliations.

Ready to submit your research? Choose BMC and benefit from:

- fast, convenient online submission

- thorough peer review by experienced researchers in your field

- rapid publication on acceptance

- support for research data, including large and complex data types

- gold Open Access which fosters wider collaboration and increased citations

- maximum visibility for your research: over $100 \mathrm{M}$ website views per year

At BMC, research is always in progress.

Learn more biomedcentral.com/submissions 